Ks. Krzysztof Czermak*

Uniwersytet Papieski Jana Pawła II w Krakowie

Wydziat Teologiczny Sekcja w Tarnowie

\title{
AKTULANE ZAANGAŻOWANIE MISYJNE DIECEZJI TARNOWSKIEJ W KONTEKŚCIE 225-LECIA JEJ ISTNIENIA KOŚCIÓŁ, KTÓRY JEST W TARNOWIE - POSŁANIA MISJONARZY I ICH KONSEKWENCJE
}

Stowa kluczowe

posłania misjonarzy - powinność Kościoła wynikająca z obowiązku szerzenia Ewangelii; współpraca misyjna - partycypacja w dziele misyjnym Kościoła powszechnego czy partykularnego na rzecz głoszenia Ewangelii aż po krańce ziemi

\section{Treść}

I. Kościół posyłający od 38 lat

1. Kongo-Brazzaville pierwszym darbiorcą

1.1. Dar par excellence

1.2. Potrzebne świadectwo

1.3. Drugi krok tarnowskich fideidonistów

1.4. Trzecia tarnowska placówka - Brazzaville

1.5. Parafia przy sanktuarium

2. Misja w Sercu Afryki

2.1. Parafia na obrzeżach Bangui

2.2. Duszpasterstwo wśród Pigmejów

2.3. Parafia przy granicy z Kamerunem

2.4. Dla Kościoła w Bouar i dla kraju

2.5. Perła w krainie Lobaye

3. Symboliczna obecność w Czadzie

4. Ponad dwadzieścia lat w Kamerunie

* Ks. Krzysztof Czermak, doktor teologii misji, dyrektor Wydziału Misyjnego Kurii Diecezjalnej w Tarnowie, dyrektor Diecezjalnego Dzieła Misyjnego. 
5. Księża tarnowscy w Argentynie

5.1. W sanktuarium w Santa Rosa

5.2. Parafia w Macachin

6. Z Ewangelią w kraju Inków

6.1. Niedaleko Limy

6.2. Parafia w Churcampa

6.3. Parafia w Huaribamba

6.4. Parafia w Huancayo

6.5. Parafia w Marco

6.6. Parafia w Pampas

6.7. Parafia w Quillazú

7. W boliwijskich Andach

7.1. Parafia w Aiquile

7.2. La Asunta

7.3. San Julian

7.4. San Martin de Porres

8. Ewangelizacja w Brazylii

8.1. Parafia w Salwadorze

8.2. Parafia w Ourolandii

8.3. Umburanas

8.4. Varzea Nova

8.5. Bagre

8.6. Melgaço

9. Ewangelizacja na równiku

9.1. Buena Fe

9.2. Quevedo

9.3. Mocache

10. Ewangelizacja w Kazachstanie

10.1. Atyrau

10.2. Chromtau

10.3. Karaganda

II. Osadzona w wierze wieloletnia współpraca misyjna

1. Współpraca duchowa i materialna w ramach Diecezjalnego Dzieła Misyjnego

2. Wizyty pasterskie biskupów tarnowskich

Każde posłanie w Kościele niesie w sobie wymiar daru. Jest bowiem ten, kto posyła (obdarowuje, dzieli się) i ten, który przyjmuje (zostaje obdarowany). Między nimi rozciąga się przestrzeń daru, którą jest sam posłany, a raczej jego wiara, świadectwo, entuzjazm.

W języku misjologicznym „darem wiary” zwykliśmy nazywać księdza diecezjalnego pracującego na misjach, który bywa tak określany od 1957 roku, kiedy Pius XII opublikował swą słynną encyklikę Fidei donum (Dar wiary). Encyklika 
ta otwiera nową kartę w historii misyjności Kościoła zarówno powszechnego, jak i partykularnego.

Apel Papieża skierowany jest przede wszystkim do biskupów diecezjalnych, którzy ,zostali konsekrowani nie tylko dla jakiejś diecezji, ale i dla zbawienia całego świata", ale również pośrednio do kapłanów diecezjalnych, którzy winni mieć bezpośredni udział w trosce swojego biskupa w głoszeniu Ewangelii na całym świecie. Apel ten jest jakby pierwszym akcentem, który składa się na teologię kapłaństwa podaną w nauce Vaticanum $\mathrm{II}^{2}$ czy sformułowaną w adhortacji posynodalnej Jana Pawła II o kapłaństwie ${ }^{3}$, która wymaga od prezbiterów zrozumienia, aby ich życie stało się darem również dla całego Kościoła. W perspektywie więc teologii daru łatwo zrozumieć życzenie Jana Pawła II wypowiedziane w Redemptoris missio, aby wśród prezbiterów zarówno Kościołów starych, jak i młodych, wzrastał duch misyjnego otwarcia, który poprowadzi ich głosić Ewangelię aż po krańce ziemi ${ }^{4}$.

\section{KOŚCIÓŁ POSYŁAJĄCY OD 38 LAT}

Do konkretnej odpowiedzi Kościoła tarnowskiego na apel zawarty w Fidei donum, choć - przyznajmy to - nie do końca świadomie ze strony kapłanów doszło w 1973 roku, kiedy biskup tarnowski Jerzy Ablewicz posłał swoich pierwszych ${ }^{5}$ czterech księży diecezjalnych do Konga-Brazzaville. To posłanie otworzyło stałą drogę dzielenia się darem wiary przez Kościół tarnowski, zgodnie z synodalną deklaracją Ad imaginem Ecclesiae universalis. W Synodzie Kościoła tarnowskiego znajdujemy bowiem zapis, że Kościół tarnowski pragnie być wiernym obrazem Kościoła powszechnego - ze swej natury misyjnego - przez posyłanie misjonarzy ${ }^{6}$.

\section{Kongo-Brazzaville pierwszym darbiorcą}

Fakt wyjazdu pierwszych fideidonistów przyczynił się niewątpliwie do rozwoju świadomości misyjnej w Kościele tarnowskim i do decyzji o wyjazdach

1 Pius XII, Encyklika Fidei donum, nr 8; Sobór Watykański II, Dekret o misyjnej działalności Kościoła Ad gentes, nr 38. Por. także: Sobór Watykański II, Konstytucja dogmatyczna o Kościele Lumen gentium, nr 23; Sobór Watykański II, Dekret o pasterskich zadaniach biskupów Kościele Christus Dominus, nr 6.

2 Por. Sobór Watykański II, Dekret o misyjnej działalności Kościoła Ad gentes, nr 39; Sobór Watykański II, Dekret o posłudze i życiu prezbiterów Presbyterorum ordinis, nr 4, 10.

3 Por. Jan Paweł II, Adhortacja apostolska Pastores dabo vobis, nr 18.

4 Por. Jan Paweł II, Encyklika Redemptoris missio, nr 68.

5 Przymiotnik ,„pierwsi” odnosi się do tych prezbiterów diecezji tarnowskiej, którzy dali początek regularnym wyjazdom na misje. Pierwszym bowiem księdzem w ogóle, który podjął pracę poza Europą (w Brazylii), był ks. Jan Jarosz zmarły w Kurytybie, a pochowany w kościele w Quatro Barras, gdzie - już jako orionista - był proboszczem. Po nim, w 1963 roku, do tego samego kraju udał się ks. Tadeusz Adamczyk i przepracował w nim prawie 40 lat.

6 Por. IV Synod Diecezji Tarnowskiej, Kuria Diecezjalna, Tarnów 1990, IV, stat. 71. par. 1. 
następnych kapłanów. Właśnie pod wpływem zgłoszeń, a potem wyjazdu pierwszych misjonarzy, na misje zgłosił się kolejny kapłan, którym był ks. Stefan Wal. Dołączył on do pierwszej czwórki już w 1974 roku.

W perspektywie kolejnych zgłoszeń i posłań (biskup Jerzy Ablewicz, za wielkimi wyjątkami, posyłał na pracę misyjną po dwóch, po trzech, a nawet po czterech kapłanów), w 1976 roku wyjechało dwóch fideidonistów, w $1977^{7}$ jeden, a w 1979 roku czterech.

W sumie z Konga-Brazzaville wyjechało 24 misjonarzy. Rozpiętość czasu ich pracy była różna - od dwudziestu pięciu lat do półtora roku8 ${ }^{8}$ Dzisiaj wśród 4 pracujących tam misjonarzy tarnowskich są kolejni długodystansowcy: ks. Józef Piszczek (najdłużej dziś pracujący w Kongo z obecnych w nim misjonarzy tarnowskich, bo 24 lata minęło 30 września), ks. Marian Pazdan (21 lat) i ks. Bogdan Piotrowski (21 lat). Przyczyny opuszczenia Konga przez kapłanów tarnowskich były różne: wojna domowa, zdrowie, powody polityczne, zamierzona osobista decyzja, wezwanie przez biskupa, a nawet oskarżenie o dysponowanie czarodziejską mocą. Jeden - ks. Jan Czuba pozostał na miejscu do końca, ginąc śmiercią męczeńską. Spośród byłych misjonarzy 7 powróciło do rodzimej diecezji, 13 pozostało na zachodzie Europy (Francja 10, Belgia 2, Niemcy 1), 1 w USA, 1 w Kanadzie, 2 nie żyje.

W roku 1988 w Kongo-Brazzaville pracowało 19 tarnowskich kapłanów. Obecnie $\mathrm{w}$ granicach kraju pozostaje $\mathrm{w}$ trzech diecezjach czterech misjonarzy: dwóch na północy i dwóch na południu. Są oni praktycznie jedynymi europejskimi misjonarzami w swoich Kościołach partykularnych. Na siedem diecezji istniejących obecnie w Kongu, w pięciu ewangelizowali nasi kapłani. Samodzielnych placówek objętych obecnością i działalnością tarnowskich fideidonistów od początku ich obecności do dnia dzisiejszego było 19. Oto one: Oyo, Gamboma, Brazzaville, Louvakou, Kibangou, Mindouli, Loulombo, Loubomo, Mbanza-Nganga, Nkayi, Divenié, Nyanga, Kimongo, Mbinda, Missafou, Owando, Ouesso, Mpouya i Ngo. W czterech pierwszych do dnia dzisiejszego pracują misjonarze z Tarnowa.

\subsection{Dar par excellence}

Obecność i praca księży tarnowskich w Kongu-Brazzaville przez 38 lat to ogrom dobra pozostawionego i przekazywanego tam pod postacią ewangelizacji

7 Trzeba zaznaczyć, że w Kongu od tegoż roku w dwóch misjach z tarnowskimi księżmi współpracują siostry józefitki. Wśród pierwszych czterech sióstr misjonarek, trzy pochodziły z tarnowskiej diecezji.

8 Księża Wojciech Mach i Stanisław Łacny opuścili Kongo po 25 latach misjonarskiej pracy i obecnie pracują na Korsyce i pod Paryżem. Ks. Stefan Wal pracował 24 lata, ks. Józef Kordek 23 lata, a ks. Józef Ziobroń 17 lat w Kongu i 3 w RCA. 
i działania na rzecz promocji człowieka. Wzrost liczby ochrzczonych, większa świadomość religijna wiernych, kościoły, kaplice, szkoły, różnej użyteczności domy, dzieła charytatywne - świadczą o tym same za siebie. Jednak złożona tam ofiara męczeńskiej krwi naszego rodaka, przewyższa wszystkie dary, których autorami byli i są księża z Tarnowa. Ksiądz Jan Czuba złożył największy dar - dar swojego życia.

Jego śmierć jest „,dopełnieniem ofiarnej, 25-letniej pracy kapłanów tarnowskich na misjach w Kongu" . Jest jednocześnie wyzwaniem do podjęcia autentycznego zapału misyjnego, który w radykalny sposób ukazał w sobie ks. Jan ${ }^{10}$. W kadrze historii wyznaczonej przez 38 lat ofiarnej posługi, postać księdza Jana Czuby, jedynego polskiego misjonarza-męczennika fideidonisty, jawi się jako ścięty kwiat, który jest wyzwaniem nie tylko dla Kościoła tarnowskiego, ale i całej wspólnoty Kościoła lokalnego w Polsce. Zaprasza bowiem ten Kościół do złożenia hojnego daru wiary dla Kościoła w stanie misji.

\subsection{Potrzebne świadectwo}

Na 28 tarnowskich misjonarzy, którzy dłuższy lub krótszy okres swego kapłaństwa poświęcili kongijskim misjom, 4 jeszcze ofiarnie w nich partycypuje. Choć tamtejszy Kościół zapewnia siły duszpasterskie w postaci rodzimych kapłanów, nad których formacją w niejednym przypadku pracowali księża tarnowscy, to świadectwo o miłości do Chrystusa i Kościoła ze strony synów tarnowskiej diecezji jest ciągle cennym darem dla wspólnoty eklezjalnej w Kongu.

Placówką, która od 1973 roku znajduje się w rękach tarnowskich fideidonistów jest parafia św. Radegondy w Oyo w diecezji Owando, której biskupem od kwietnia 2011 roku jest Victor Abagna Mossa. Do Oyo pierwsi trzej tarnowscy fideidoniści przybyli w 1973 roku. Od 1987 roku pracuje tam ks. Józef Piszczek, a od 1993 jest proboszczem ${ }^{11}$. Początkowo „wielka misja Oyo" miała powierzchnię około 10 tys. $\mathrm{km}^{2}$ (obecnie 5 tys.), misjonarze obsługiwali 20 kaplic w wioskach.

W roku 2006 po raz pierwszy w parafii Oyo miały miejsce święcenia kapłańskie, które przyjęli między innymi dwaj tamtejsi rodacy. Jest to, w jakimś sensie, owoc pracy tarnowskich misjonarzy.

Dziełem ks. Józefa jest rozbudowa kościoła i budowa podstawowej szkoły katolickiej dla 250 dzieci, oraz gimnazjum. Projekty związane z edukacją

9 Komunikat Biskupa Tarnowskiego o śmierci ks. Jana Czuby, 6 listopada 1998 roku.

10 Por. K. Czermak, Męczeńska śmierć ks. Jana Czuby dopetnieniem ofiarnej pracy tarnowskich misjonarzy w Kongo, „Currenda” 1 (1999), s. 79-80.

11 Wcześniej proboszczami byli ks. Stanisław Jeż, ks. Stanisław Łacny, ks. Wojciech Mach, a po nim ks. Stanisław Pawłowski do 1993 roku. Pracował tu również ks. Józef Kiwior (19921997), po przepracowaniu w parafiach na południu Konga w Nkayi, Loubomo, Mbinda, Kimongo (1988-1992). 
sfinansowała diecezja tarnowska ${ }^{12}$. Parafia dysponuje samochodem zakupionym przez diecezję tarnowską.

\subsection{Drugi krok tarnowskich fideidonistów}

Od 1974 roku nasi misjonarze prowadzą misję w Gamboma ${ }^{13}$, położoną w tej samej diecezji, $100 \mathrm{~km}$ od Oyo. Obowiązki proboszcza od 1 października 2006 roku spełnia tu ks. Tomasz Kania. Parafia w Gamboma pw. św. Piusa X obsługuje obecnie 15 kaplic. Na całym jej obszarze mieszka około 65 tys. mieszkańców, z których około 9 tys. to katolicy. Na przestrzeni historii z parafii Gamboma wydzielono trzy nowe parafie.

Wśród wielu dzieł dokonanych na terenie misji Gamboma, na szczególną uwagę zasługuje wybudowane w latach 2001-2003 Collège Catholique czyli katolicka szkoła ponadpodstawowa, która w rankingu krajowym w swojej kategorii w roku 2006 odniosła sukces zajmując pierwsze miejsce. Jej budowniczym był ks. Józef Kordek. Dokończenia szkoły gimnazjalnej dokonał ks. Tomasz Kania. W roku 2004 rozbudowana została również katolicka szkoła podstawowa, a następny projekt objął budowę przedszkola. Kolejnym darem dla misji w Gamboma jest studnia głębinowa. Te przedsięwzięcia finansowane były przez diecezję tarnowską z funduszu kolędników misyjnych z okresu Bożego Narodzenia 2004, 2007, 2008 i 2009 roku.

W październiku 2010 roku inaugurowano pierwsza klasę Katolickiego Liceum, które jest jedyną tak placówką w diecezji Owando. W marcu 2010 roku Dyrekcja Szkoły otrzymała list gratulacyjny z ramienia Komisji Episkopatu Konga ds. Edukacji Katolickiej, wyrażający uznanie za całokształt wysiłków. Parafia otrzymała dwa razy pieniądze na zakup samochodów.

\subsection{Trzecia tarnowska placówka-Brazzaville}

W Brazzaville, którego biskupem jest abp Anatole Milandou - nieprzerwanie od 1976 roku tarnowscy księża diecezjalni prowadzą parafię pw. Jezusa Zmartwychwstałego. Powierzył im ją, zamordowany rok później, kardynał Emil Biayenda. W mszach niedzielnych uczestniczy około 3 tys. wiernych. Owocem pracy naszych księży jest to, że również na porannej mszy św. w dni powszednie zbiera się od 300 do 500 wiernych. Od 1998 roku proboszczem jest ks. Bogdan Piotrowski, a w pracy parafialnej pomagają mu dwaj miejscowi wikariusze.

12 Z ofiar zebranych kolędników misyjnych w 2002 roku diecezja tarnowska przekazała na ten cel 30 tys. euro.

13 Aż 22 lata spędził w tej misji ks. Józef Kordek, z czego 19 lat (do 1 października 2006) zajęło mu proboszczowanie. Pracował tu wcześniej ks. Stefan Wal (1974-1986), ks. Andrzej Piotrowski (1974-1976), ks. Bronisław Puchała (1980-1988), ks. Stanisław Boroń (1988-1991) i ks. Jan Betlej (1992-1999), z przerwą (1997-1998) w Kamerunie. 
W parafii istnieje m.in. stowarzyszenie dzieci Yambote. W ich formacji katechetycznej i misyjnej udział mają kolędnicy misyjni diecezji tarnowskiej. Na przestrzeni lat proboszczowania ks. Bogdana parafia otrzymała dwa samochody $\mathrm{z}$ diecezji tarnowskiej.

\subsection{Parafia przy sanktuarium}

Czwartą parafią „tarnowską” w Kongu-Brazzaville jest Louvakou w diecezji Nkayi, której biskupem od 2002 roku jest Daniel Mizonzo. Proboszczem jej jest ks. Marian Pazdan. Tu ks. Marian buduje duże sanktuarium Bożego Miłosierdzia opierając się finansowo w dużej mierze na ofiarach pochodzących z diecezji tarnowskiej. W samym Louvakou, podobnie jak w Kibangou, zrealizował projekt kolędników misyjnych czyli dom dla dzieci „Inzo ya kilengi” W okresie od 2002 roku otrzymał od Kościoła tarnowskiego dwa samochody.

\section{Misja w Sercu Afryki}

W roku 1987 abp Jerzy Ablewicz otworzył dla swoich księży drugi kraj do ewangelizacji. Była nim Republika Środkowoafrykańska. Otwarcie nowej misji w tym kraju wyznaczyła okoliczność wydalenia przez ambasadę radziecką z Konga-Brazzaville w 1986 roku ks. Józefa Ziobronia ${ }^{14}$. Pierwszą parafią tarnowskich księży było Bimbo na przedmieściach stolicy Bangui, którą tworzyli ks. Józef Ziobroń, ks. Krzysztof Czermak (od 1988 roku) i ks. Marek Muszyński (od 1989 roku). Obecnie w kraju tym pracuje 9 fideidonistów z Tarnowa w trzech diecezjach i na pięciu różnych placówkach.

Księża tarnowscy w Sercu Afryki pracują od prawie dwudziestu pięciu lat. Na siedemnastu misjonarzy tarnowskich związanych z ewangelizacją w Republice Środkowoafrykańskiej, ośmiu opuściło ją i powrócili do Polski (5) lub udali się do Francji (3).

Dla podkreślenia troski o teraźniejszość i przyszłość ewangelizacji tego kraju, na praktyki misyjne od 2008 roku ze swoim ojcem duchownym, dawnym tam misjonarzem, udaje się w każde wakacje trzech kleryków.

\subsection{Parafia na obrzeżach Bangui}

Bimbo jest dzielnicą stolicy Bangui będącego jednocześnie stolicą archidiecezji, której administratorem apostolskim jest o. Dieudonné Nzapalainga Cssp. Tutaj proboszczem parafii pw. św. Antoniego z Padwy od sierpnia 2011 roku jest ks. Krzysztof Mikołajczyk. Rolę nietypowego - bo prawie z dwudziestoletnim stażem - wikariusza, przejmie od września 2011 roku ks. Marek Muszyński. Parafia ta

14 Więcej na ten temat, zob. K. Czermak, Zapisani w Sercu Afryki, Tarnów 2007. 
jest największą placówką tarnowskich misjonarzy. Dzielnicę Bimbo zamieszkuje ok. 20 tys. ludzi. Chrześcijan-katolików ciągle przybywa, a obecnie jest ich około 8 tysięcy. Następstwem przyrostu katolików w Bimbo była, dokonana w 1997 roku rozbudowa kościoła, której dokonał ks. Marek Muszyński.

W Eucharystii niedzielnej w kościele parafialnym uczestniczy około 2 tysiące osób, a w czterech pozostałych miejscach kultu w centrum parafii - kolejne 2 tysiące.

Parafia, jak każda, zwłaszcza miejska parafia afrykańska, tętni od działalności grup i ruchów. Na miejscu w Bimbo jest ich wszystkich 36. Parafia dysponuje domem dla dzieci ulicy, który jest całkowitym darem kolędników misyjnych z 2001 roku. Korzysta z niego codziennie 60 dzieci. Tutaj otrzymują posiłek przed nauką w szkole lub po niej, tutaj mogą odrobić swoje lekcje, tutaj też otrzymują korepetycje. Dzieciom z tego domu parafia opłaca szkołę.

Tarnowscy księża obsługują również 41 kaplic w wioskach zamieszkiwanych przez około 30 tys. ludności.

$\mathrm{Na}$ terenie misji w trzech wioskach nad rzeką Oubangui (Mondouli, Modale i Sekia Mote) zostały wybudowane przez ks. Wojdaka i ks. Kowalika szkoły, które będą służyć ok. 750 dzieciom z siedmiu różnych wiosek, nawet z Demokratycznej Republiki Konga. Przedsięwzięcia te związane są z akcją kolędników misyjnych z okresu Bożego Narodzenia 2003 (szkoła w Sekia Mote - sfinansowana została przez kleryków WSD w Tarnowie na sumę 105 tys. zł). Szkoły te są również utrzymywane przez diecezję tarnowską. Kolejna pomoc kolędników to wybudowanie jedenastu studni głębinowych oraz 26 kaplic we wioskach - dzieło w większości ks. Kowalika.

Działalność charytatywna parafii prowadzonej przez naszych księży obejmuje różne wymiary ${ }^{15}$.

Nasi misjonarze poruszają się samochodami przekazanymi im przez diecezję tarnowską. Na przestrzeni siedemnastu lat otrzymali ich cztery.

\subsection{Duszpasterstwo wśród Pigmejów}

W roku 1998 nasi księża rozpoczęli pracę w powstałej kilka lat wcześniej diecezji Mbaïki, której pierwszym biskupem jest Włoch Rino Perin. Od początku diecezja ta stała się „bliźniaczą” w stosunku do diecezji tarnowskiej. Świadczona pomoc dotyczy nie tylko parafii, w których pracują nasi misjonarze. Symbolem

15 Jeden z projektów realizowany przez kolędników misyjnych w 2010 roku ( 8 tys. euro) dotyczył pomocy biednym dzieciom w zakresie finansowania szkoły dla nich, leczenia (AIDS, malaria, zarobaczenie) oraz remontu lub budowy skromnych domów dla dzieci osieroconych. Inny zapewnił naprawę lub zakup wózków inwalidzkich dla 12 osób (2 tys. euro). Od dawna niesiona jest pomoc osobom kalekim fizycznie, które od osób pojedynczych lub zespołów (np. klasy) otrzymują jednorazową dotację na prowadzenie działalności gospodarczej, by utrzymać siebie. Na ten temat zob. „Głoście Ewangelię” 2 (2005), s. 41-42 i www.misje.diecezja.tarnow.pl. 
tego jest sfinansowana studnia głębinowa dla niższego seminarium im. bł. Jana Pawła II, w którym aktualnie przebywa około 20 chłopców.

Nasi misjonarze ks. Mieczysław Pająk (proboszcz od 2003 roku) i ks. Mateusz Dziedzic (2009-2011, od października 2011 proboszcz w Wantinguera) pracują w Bagandou, gdzie plebanię postawił ks. Marek Muszyński. Mają do obsługi w terenie dwanaście wiosek z kaplicami. Dużą część ich posługi stanowi ewangelizacja Pigmejów. Misja w Bagandou została objęta w roku 2000 projektem, który przewidział również dwuizbową szkołę dla pigmejskich dzieci. Darem kolędników misyjnych jest również osiem studni głębinowych.

Nasi księża korzystają z samochodów zakupionych przez diecezję tarnowską, których do tego czasu otrzymali trzy.

\subsection{Parafia przy granicy z Kamerunem}

W diecezji Bouar, której pierwszym biskupem jest Włoch Armado Gianni, 50 km od granicy z Kamerunem znajduje się wioska Baboua, w której mieszka około 700 katolików. Kilkakrotnie więcej jest chrześcijan (kilka tysięcy) z Kościoła luterańskiego. Obecni są również chrześcijanie innych Kościołów protestanckich, w tym baptyści. Pod koniec 1997 roku misję w Baboua objęli: ks. Marek Mastalski i ks. Jerzy Bubułka. Prowadzą ją do dzisiaj.

Przy parafii, w istniejącym już budynku w roku 2003 zostało założone przedszkole, do którego w roku 2010/2011 uczęszczało 42 dzieci różnych wyznań (29 katolików), również niechrześcijańskich. W roku 2010 nastąpiła jego rozbudowa ${ }^{16}$. Obecnie dyrektorem przedszkola od września 2009 roku jest pani Iwona Ligas, świecka misjonarka. Przedszkole bardzo dobrze przygotowuje dzieci do podjęcia nauki w szkole podstawowej.

Również tutaj misjonarze korzystają z samochodu, który tym razem diecezja tarnowska zakupiła wspólnie z MIVĄ polską i austriacką. Nasi misjonarze otrzymali również z diecezji tarnowskiej w roku 2001 aparat prądotwórczy.

\subsection{Dla Kościoła w Bouar i dla kraju}

W diecezji Bouar w Yolé, gdzie miejscowy biskup w 1997 roku utworzył tzw. „niższe i średnie seminarium duchowne” św. Piotra, nasi księża zaangażowani są nie tylko duszpastersko. Obecnie rektorem seminarium jest ks. Marek Dziedzic, a w pracy tej od lutego 2011 roku pomaga mu ks. Piotr Boraca. Pierwszym rektorem seminarium został ks. Mirosław Gucwa i sprawował tę funkcję do 2004 roku. Jego praca wspomagana była przez ks. Eugeniusza Szyszkę (1997-2001), który

16 Dokonała się ona dzięki funduszom (ponad 50 tys. zł) przekazanym z festynu misyjnego w Tylmanowej w roku 2007. W roku 2010 kolędnicy misyjni wsparli działanie przedszkola sumą 1200 euro. 
m.in. był ekonomem tej instytucji. Od sierpnia 2011 roku jest on proboszczem katedry, ale pełni przede wszystkim od 2009 roku funkcję wikariusza generalnego. Sprawuje funkcję kapelana więzienia, dla którego lokatorów diecezja tarnowska wybudowała za ponad 13 tys. studnię głębinową, by stworzyć podstawowe warunki życia i higieny dla 50-60, a nawet 90 więźniów.

Diecezja tarnowska ma swój duży wkład w budowę, organizację i funkcjonowanie seminarium w Yolé, czego symbolem materialnym jest przekazanie terenowego samochodu, który ułatwia funkcjonowanie tej niezwykle ważnej instytucji - oraz wielu innych wartościowych darów.

\subsection{Perta w krainie Lobaye}

Cenną pomocą dla parafian z Bagandou i okolic, których swą troską duszpasterską obejmują nasi księża, jest centrum zdrowia powstałe jako „wielkie dzieło miłosierdzia" przede wszystkim z myślą o promocji Pigmejów. Do realizacji projektu przystąpił ks. Marek Muszyński. W roku 2003 dokończeniem budowy i wyposażeniem szpitala i domu zajął się ks. Mieczysław Pająk.

Szpital nazwany został przez jednego z włoskich lekarzy ,perłą Lobaye"17 - czyli skarbem okolicy Lobaye. Początek projektu tego dzieła promocji ludzkiej związany jest z kolędnikami misyjnymi z okresu Bożego Narodzenia 2000 roku. Dotychczas wybudowano trzy budynki szpitalne, sale na hospitalizację i mały dom mieszkalny dla personelu z Polski. Projektem objęte jest również funkcjonowanie szpitala, które zamyka się w kwocie około 55 tys. euro rocznie. Od początku budowa i funkcjonowanie tej jednostki pochłonęło ponad $1 \mathrm{mln} 710$ tys. zł (około 430 tys. euro). Szpital posiada blok operacyjny, salę porodową, oddziały ogólny i pediatrii z 50. łóżkami, laboratorium, aptekę, gabinet dentystyczny, aparat USG, własną studnię głębinową i agregat prądotwórczy. W roku 2010 skonsultowano prawie 4 tys. pacjentów, a hospitalizowano ponad 1500. Personel szpitalny z jego dyrektorem p. Elżbietą Wryk z Tarnowa liczy - w zależności od liczby woluntariuszy z Polski - do 19 osób.

\section{Symboliczna obecność w Czadzie}

W Czadzie Kościół tarnowski jest reprezentowany przez jednego misjonarza pracującego w samej N'Djamenie, gdzie pasterzem jest abp Matthias Ngarterii. Tym misjonarzem jest ks. Stanisław Worwa. Podjął on pracę w tym kraju w jesieni 2004 roku.

W maju 2009 został proboszczem parafii pw. św. Rodziny w dzielnicy N'Djameny - Dembe. Zamieszkuje ją około 4 tys. wiernych. W niedzielę na mszy św.

17 Więcej na temat historii powstania szpitala i początków działalności, zob. K. Czermak, Zapisani w Sercu Afryki, dz. cyt., s. 134-145. 
jest 2 tys. wiernych, a w dzień powszedni uczestniczy w niej 200 osób. Od września 2010 ks. Stanisław pełni funkcję dziekana dekanatu. Jest jedynym Europejczykiem w dekanacie.

Cała N'Djamena i okolica ewangelizowana jest przez diecezjalne radio „Arc en Ciel". Jego dyrektorem od marca 2010 roku jest ks. Stanisław. Program radia przewidziany jest dla wszystkich, ale szczególnie ma on wymiar religijny i korzystają z niego katolicy.

Również misjom w Czadzie diecezja tarnowska pomogła przez zakup dwóch samochodów.

Dla stworzenia kompletnego obrazu historycznego trzeba dodać, że symboliczną i ofiarną obecnością tarnowskich fideidonistów cieszyła się diecezja tarnowska również w dwóch innych krajach Afryki: Republice Południowej Afryki (19912002) i Kamerunie (1997-1998).

\section{Ponad dwadzieścia lat w Kamerunie}

Wśród misjonarzy posyłanych przez diecezję tarnowską są również - jak to było wspomniane - ludzie świeccy. Przewodzi im pani Ewa Gawin, która w Kamerunie poświęca się już od 1990 roku. Jej praca związana jest z miastem, które jest stolicą archidiecezji i wschodniego Kamerunu - Bertoua, której biskupem jest abp Joseph Atanga. Na początku podjęła pracę jako pielęgniarka-kierownik ośrodka zdrowia w Bertoua. W latach 1994-1997 koordynowała całą służbą zdrowia w archidiecezji Bertoua, później przez rok była za nią odpowiedzialna w trzech diecezjach. W tej dziedzinie stała się specjalistką i od 2000 roku reprezentowała całą metropolię w Komisji Episkopatu ds. zdrowia. W późniejszym czasie zadaniem koordynatorki była również opieka w całej diecezji nad niepełnosprawnymi ruchowo. Od 1 października 2010 roku zajmuje się prowadzeniem budowy nowej szkoły dla głuchoniemych. Szkoła powstała w 2006 roku i jest jedyną tego typu placówką na wschodzie kraju. Opiekuje się też niepełnosprawnymi ruchowo, organizowaniem konsultacji i pomocy dla nich, odwiedza ich w wioskach, pomaga w zakupie wózków inwalidzkich, protez, kuli. Tę pomoc finansuje przede wszystkim diecezja tarnowska.

Nie można nie wspomnieć o jej zaangażowaniu w pracy w miejscowym więzieniu. To duży obiekt, w którym przebywa około 600 więźniów: mężczyzn, małolatów i kobiet z dziećmi.

\section{Księża tarnowscy w Argentynie}

Pięć lat po wyjeździe pierwszych misjonarzy diecezjalnych do Konga, biskup Jerzy Ablewicz, odpowiadając na zaproszenie biskupa diecezji Lomas de Zamora - Desiderio Collino, posłał w 1978 roku pierwszych dwóch kapłanów za Ocean do Argentyny. Byli nimi księża: Tadeusz Mastej i Kazimierz Pres, do których po 
latach w dwóch rzutach dołączyła szóstka księży. Na ośmiu księży tarnowskich związanych z ewangelizacją w Argentynie, sześciu zakończyło już pracę duszpasterską w tym kraju.

\subsection{W sanktuarium w Santa Rosa}

W Santa Rosa, stolicy diecezji o tej samej nazwie, w styczniu 1982 parafię pw. Matki Bożej Fatimskiej objął ks. Aleksander Piszczek i jest tu proboszczem do chwili obecnej. Jest ona jedną z ośmiu w mieście i liczy 20 tys. mieszkańców. Tu nasz kapłan wybudował sanktuarium z koronowaną później figurą Matki Bożej.

\subsection{Parafia w Macachin}

Druga „tarnowska” parafia w stanie La Pampa znajduje się w miasteczku Macachin i nosi wezwanie Matki Bożej Różańcowej. Proboszczem od grudnia 1998 roku jest tu ks. Tadeusz Mastej, który w Argentynie duszpasterzuje od 1978 roku.

\section{Z Ewangelią w kraju Inków}

W 1991 roku biskup tarnowski Józef Życiński otworzył nowy kraj, do którego zaczęli regularnie wyjeżdżać księża tarnowscy. Początek ich misji dokonywał się w trudnym momencie historycznym. Zamordowanie bowiem dwóch polskich franciszkanów (o. Zbigniew Strzałkowski pochodzi z diecezji tarnowskiej) przez lewackich terrorystów z ugrupowania „Świetlisty szlak”, wytworzyło atmosferę niebezpieczeństwa i niepewności dla duchownych. Nie ograniczyło to kolejnych wyjazdów i w sumie dwudziestu tarnowskich księży związało się z ewangelizacją w Peru. Jedenastu opuściło już ten kraj.

\subsection{Niedaleko Limy}

W Lurín koło Limy jest dom, w którym mieszka ponad 100 dzieci w wieku od 3 do 18 lat. Aż 60 proc. to sieroty, a 40 proc. to dzieci ulicy. Historia powstania domu związana jest z Janem Pawłem II, który zasugerował to dzieło. Kierownictwo domem w roku 2006 przejął ks. Czesław Faron.

\subsection{Parafia w Churcampa}

Miasteczko Churcampa leży $520 \mathrm{~km}$ na południowy wschód od Limy (12-13 godzin jazdy samochodem) na wysokości 3200 m n.p.m., w diecezji Huancavelica, której biskupem jest Isidro Barrio Barrio. Tu pracują dwaj tarnowscy kapłani: ks. Grzegorz Łukasik - od 2007 roku proboszcz i ks. Wiesław Tworzydło, dla którego Churcampa jest czwartą peruwiańską parafią. 
Ważnym obiektem w parafii jest Centrum pastoralne, w którym od roku 2010 każdego miesiąca odbywają się dni skupienia dla nauczycieli religii, dla dziewcząt, chłopców, dla dorosłych. Na co dzień w tym budynku ma miejsce katecheza.

Księża mają do obsługi około 50 kaplic w wioskach zamieszkiwanych przez około 15 tys. katolików. Dużą pomocą w dojeździe do nich i w codziennej pracy są samochody, których diecezja tarnowska na przestrzeni ostatnich dziesięciu lat podarowała cztery.

\subsection{Parafia w Huaribamba}

Parafię pw. św. Anny w Huaribamba w diecezji Huancavelica prowadzi ks. Wiesław Mikulski. Przez kilkadziesiąt lat brakowało tu stałej obecności księdza. Niektóre wioski mogły się cieszyć jego wizytą raz do roku.

W lutym 2007 roku ks. Wiesław rozpoczął budowę nowego kościoła parafialnego i po 3,5 latach uwieńczył swoje dzieło konsekracją świątyni. Do parafii należy około 50 wiosek, w tym $45 \mathrm{z}$ kaplicami. Teren pracy duszpasterskiej jest bardzo rozległy, rozciąga się na wysokości od 2500 do 4000 m n.p.m., zamieszkiwany przez 20 tys. ludzi, z których 75 proc. to katolicy. W pracy wielką pomocą jest samochód otrzymany z diecezji.

\subsection{Parafia $w$ Huancayo}

Miasto to leży $320 \mathrm{~km}$ na wschód od Limy na wysokości 3200 m n.p.m. Jest to równocześnie stolica archidiecezji, której pasterzem jest abp Pedro Ricardo Barreto Jimeno. W parafii Pio Pata, która liczy ok. 20 tys. mieszkańców, duszpasterzują ks. Jacek Olszak wraz z ks. Antonim Lichoniem. Rocznie udzielają ok. 250 chrztów. Parafia, będąca w rękach księży tarnowskich od 1997 roku, otrzymała od diecezji tarnowskiej dwa samochody.

\subsection{Parafia w Marco}

Marco położone jest na wysokości 3500 m n.p.m., natomiast niektóre z 13 wiosek dojazdowych osiągają poziom $3900 \mathrm{~m}$. Od kwietnia roku 2008 roku w tutejszej parafii św. Marii Magdaleny pracuje ks. Krzysztof Gabryś. Również księża z Marco otrzymali dar od diecezji tarnowskiej w postaci dwóch samochodów.

Parafia jest odbiorcą dwóch projektów finansowanych przez kolędników misyjnych 2010. Pierwszy projekt obejmujący dwa lata kalendarzowe ma na celu dotarcie do dzieci z rodzin najuboższych i danie im szansy rozwoju w różnych dziedzinach życia. To przedsięwzięcie pomoże około 60 dzieciom z Marco i wiosek przyległych. Drugą formą wsparcia przez kolędników misyjnych jest pokaźny udział (10 tys. euro) w zakupie busa przywożącego dzieci do szkoły. 


\subsection{Parafia w Pampas}

W tej samej diecezji Huancayo parafię pw. św. Piotra w Pampas w roku 2005 objął ks. Robert Zając. Obszar obejmowany duszpasterstwem zajmuje około 120 wiosek, z których każda ma swoją kaplicę. Potrzeba samochodu, o który zadbała diecezja tarnowska jest więc ewidentna.

W roku 2008 ks. Robert rozpoczął budowę Centrum Pastoralnego. W nim będą organizowane kursy szycia, gotowania, pieczenia, uprawy roli, opieki nad starszymi osobami. Oprócz tego ułatwi ono przede wszystkim pracę duszpasterską z dziećmi i młodzieżą.

\subsection{Parafia w Quillazú}

W marcu 2008 roku, po prawie trzech latach pracy w wikariacie apostolskim San Ramón, którego biskupem jest Gerardo Antonio Zerdín Bukovec, pracę misyjną w Quillazú w parafii Wniebowzięcia Matki Bożej objął ks. Henryk Chlipała. To wioska licząca około 800 mieszkańców, leżąca w tzw. górnej dżungli na wysokości 1816 m n.p.m. W dniu 1 sierpnia 2011 otrzymał do opieki duszpasterskiej drugą parafię w powiatowym miasteczku Oxapampa, zamieszkiwanym przez 10 tys. mieszkańców. Do tej parafii przynależy 45 wiosek. Swoje podróże w tej strefie ks. Henryk odbywa najczęściej na motorze, gdyż teren, po którym się porusza obfituje w rzeki, przez które można się przedostać tylko kładkami. Dysponuje również samochodem sfinansowanym przez diecezję tarnowską.

Z funduszu kolędników misyjnych 2008 roku, parafia zakupiła dla 19 dzieci bus dowożący je codziennie po bezasfaltowych drogach do szkoły z odległości $17 \mathrm{~km}$.

\section{W boliwijskich Andach}

Kolejnym krajem latynoamerykańskim, do którego w 1993 roku wyjechali księża tarnowscy była Boliwia. Na dziewięciu tarnowskich księży związanych z ewangelizacją w Boliwii, pięciu opuściło już ten kraj.

\subsection{Parafia $w$ Aiquile}

Parafia w Aiquile jest jedną z 14 parafii należących do prałatury o tej samej nazwie, której biskupem jest Jorge Herbas Balderrama. Należą do niej 93 wioski, w których brak jest wody i elektryczności (do najdalszej z centrum miasteczka jest niemal $80 \mathrm{~km}$ ). Łącznie na terenie objętym duszpasterstwem mieszka około 32 tys. ludzi, z czego praktykujących w niedziele jest tylko 40 proc. Obszar parafii rozciąga się na terenie górzystym o wysokości od 2 do 3 tys. m n.p.m. Samo Aiquile położone jest na wysokości 2400 m n.p.m., a jako miasteczko rozrasta się i liczy około 15 tys. mieszkańców. Od 1999 roku pracuje tu ks. Antoni 
Kądziołka. Również ta parafia otrzymała samochód sfinansowany przez diecezję tarnowską.

\subsection{La Asunta}

Pod koniec listopada 2006 roku trzech księży tarnowskich rozpoczęło pracę w Boliwii w wikariacie apostolskim Ñuflo de Chávez ${ }^{18}$. Jego biskupem, w 50. roku istnienia, został Polak o. Bonifacy Antoni Reimann OFM.

Zdecydowaną większość parafii La Asunta, gdzie od stycznia 2008 roku jest ks. Kazimierz Stempniowski, stanowią przybysze z gór, którzy wypalają dżunglę, by zyskać pole do uprawy, a w konsekwencji, by móc utrzymać siebie i ich rodziny. Ks. Kazimierz również otrzymał samochód ze swej rodzimej diecezji.

Problemem społecznym, jak i duszpasterskim tego terenu, jest produkcja narkotyków, na której niesprawiedliwie bogacą się ludzie zajmujący się tym procederem.

\subsection{San Julian}

Miasteczko San Julian, gdzie od listopada 2006 roku pracuje ks. Paweł Żurowski (od lutego 2009 jako proboszcz), liczy około 16 tys. mieszkańców. Mniej więcej 60 proc. to ludzie ochrzczeni w Kościele katolickim, choć dużo mniej z nich uczestniczy w życiu Kościoła. Pozostały procent to ludzie przynależący do 20-30 istniejących sekt. W skład parafii wchodzi 10 wspólnot wioskowych.

\subsection{San Martin de Porres}

San Martin de Porres to wioska licząca około 700 mieszkańców. Wspólnotą parafialną w niej istniejącą przewodzi ks. Mariusz Barwacz od 2009 roku. Cała parafia składa się ze stu małych wiosek oddalonych od siebie każda od sąsiedniej około $5 \mathrm{~km}$. Jest to obszar prostokąta o wymiarach $80 \mathrm{na} 25 \mathrm{~km}$. Wioski te powstały w wyniku wykarczowań dżungli (każda rodzina otrzymała 50 ha ziemi do wykarczowania i do uprawy). Ks. Mariusz ma do obsługi 40 wiosek, które zamieszkuje około 8 tys. mieszkańców. Nic więc dziwnego, że otrzymał z diecezji tarnowskiej w roku 2009 samochód.

\section{Ewangelizacja w Brazylii}

Regularne wyjazdy naszych księży do Brazylii rozpoczęły się w roku 1995. Na piętnastu tarnowskich księży związanych z ewangelizacją w tym kraju, dziewięciu zakończyło w niej swą pracę.

18 Jest to druga (po wikariacie apostolskim San Ramon w Peru) misyjna jednostka administracyjna Kościoła pozostająca w jurydycznej zależności od Kongregacji Ewangelizacji Narodów, w której ewangelizują księża tarnowscy. 


\subsection{Parafia w Salwadorze}

Parafia pw. św. Jana Chrzciciela w São Salvador da Bahia, który jest stolicą archidiecezji mającej za swego nowego biskupa Murilo Krigera, związana jest z obecnością i pracą księży tarnowskich od 1995 roku. Od 2003 roku proboszczem parafii, jest ks. Ryszard Taraszka. Jest to już jego trzecia na brazylijskiej ziemi, gdzie przebywa od 1998 roku. Liczbę mieszkańców parafii szacuje się na 40 tys., z czego, niestety, praktykuje swą wiarę około 2 proc. czyli 800 osób. Darem diecezji dla tej parafii są na przestrzeni kilku lat dwa samochody.

\subsection{Parafia w Ourolandii}

Parafia pw. Matki Bożej Szkaplerznej w Ourolândii należy do diecezji Bonfim, w której biskupem od listopada 2006 roku jest dom Francisco Canindé Palhano. Proboszczem parafii jest ks. Jan Kaczmarczyk, pracujący tu od 2002 roku.

Ks. proboszcz bliski jest ukończenia budowy nowego kościoła, który zastąpi niewielką kaplicę dotychczas gromadzącą wiernych na modlitwie. Parafia na przestrzeni działalności w niej księży tarnowskich otrzymała z diecezji pięć samochodów.

\subsection{Umburanas}

Od początku swojej obecności w Ourolândii, księża tarnowscy obsługiwali również utworzoną w czerwcu 2001 roku parafię pw. Matki Bożej Nieustającej Pomocy w Umburanas, miasteczku liczącym 7 tys. mieszkańców. Od stycznia 2009 roku parafią administruje ks. Marek Pawełek, który w Ourolandii zorganizował ochronkę-przedszkole dla dzieci w wieku od 3 do 5 lat. Kolędnicy misyjni roku 2007 i 2009 przyszli z pomocą funkcjonowaniu tej jednostki edukacyjnej.

Ks. Marek obsługuje 28 wspólnot zamieszkiwanych przez około 7 tys. mieszkańców, z czego połowa to katolicy, a spośród nich tylko około 500 osób spotyka się z przybywającym do nich kapłanem. Do tych wspólnot ks. Marek przybywa samochodem zakupionym przez Diecezjalne Dzieło Misyjne w Tarnowie.

Tutaj też został zrealizowany pierwszy projekt kolędniczy diecezji tarnowskiej z okresu Bożego Narodzenia 1999 roku - dom dla dzieci, którego celem miała być głównie edukacja szkolna i religijna najmłodszych.

\subsection{Varzea Nova}

Tarnowscy księża objęli tę parafię w kwietniu 2007 roku po dwuletniej nieobecności kapłana. Jest ona położona $63 \mathrm{~km}$ od Ourolândii i nosi wezwanie Podwyższenia Krzyża Świętego. Proboszczem od początku jest tu ks. Roman Góra. Swoją posługą duszpasterską obejmuje również okoliczne wioski, których jest 34 . 
Zamieszkuje je około 15,5 tys. katolików. W samym miasteczku na niedzielną Eucharystię przychodzi ok. 300 osób. W wioskach jest ich razem około tysiąc.

\subsection{Bagre}

Misja w Bagre stanowi część prałatury Marajó, której biskupem jest Hiszpan José Luís Azcona Hermoso. Misja jest położona w delcie Amazonki. Swoim zasięgiem obejmuje wyspę Marajó (ok. 1/3 powierzchni Polski) oraz setki mniejszych wysp i rozlewisk.

Od maja 2003 roku proboszczem w parafii Matki Bożej z Bagre jest ks. Kazimierz Skórski. Miasteczko, gdzie znajduje się misja główna liczy 4,5 tys. mieszkańców. Reszta wspólnot rozrzucona jest na wyspach, a zamieszkuje je prawie 10 tys. ludzi. Są tu 24 kaplice, do których nasz misjonarz dopływa barką sfinansowaną przez diecezję tarnowską.

W roku 2007 ks. Kazimierz zakończył realizację kosztownego projektu - wielkiego przedsięwzięcia, którym jest wybudowanie piętrowego przedszkola dla 200 dzieci.

\subsection{Melgaço}

Pod koniec października 2007 roku ks. Tadeusz Sępek został proboszczem na terenie tej samej prałatury Marajó w parafii św. Michała Archanioła w Melgaço, miasteczka liczącego około 6 tys. mieszkańców. Podróż z Melgaço do dużego miasta Belém („wrota Ameryki”) zajmuje od 16 do 17 godzin. Ksiądz Tadeusz przybył do parafii po kilkuletniej nieobecności księdza - pierwszego kapłana wyświęconego w tej diecezji - i zaraz otrzymał z diecezji dar, którym jest barka długości $17 \mathrm{~m}$.

Do niedawna w tej prałaturze w miejscowości Afuá przez dwa lata pracował ks. Grzegorz Trojan, który przybył do Brazylii w 2004 roku.

\section{Ewangelizacja na równiku}

Do Ekwadoru, piątego i ostatniego chronologicznie kraju pozaeuropejskiego, na który otworzył diecezję tarnowską bp Wiktor Skworc, kapłani tarnowscy zaczęli wyjeżdżać w roku 2000. Podjęli oni pracę ewangelizacyjną w jednej z 23 diecezji w tym kraju - Babahoyo para los Ríos. Na jedenastu tarnowskich księży związanych z ewangelizacją w Ekwadorze, pięciu z nich opuściło już ten kraj.

Trzeba też dodać, że na praktyki misyjne do tego kraju od 2009 roku ze swoim przełożonym (w tym dawnym tam misjonarzem), udaje się w każde wakacje 2-3 kleryków.

\subsection{Buena Fe}

Pierwszą wspólnotą parafialną, którą otoczyli duszpasterską opieką księża tarnowscy była parafia św. Jacka w Buena Fe. Od października 2004 roku pracuje tu 
ks. Grzegorz Koza, od kwietnia 2006 roku ks. Tomasz Paluch, a od listopada 2009 ks. Paweł Kaim.

Nasi księża, oprócz kościoła na miejscu, w którym w niedzielę gromadzi się około 2 tys. wiernych (to wyraźny owoc pracy naszych kapłanów, pamiętając, że w momencie ich przybycia we mszy św. uczestniczyło ok. 30 osób.), obsługują też wioski, których jest 45. Mieszka w nich ok. 30 tys. mieszkańców. Samochód jest więc codziennym narzędziem ich pracy. Parafia na przestrzeni 11 lat otrzymała 4 samochody z naszej diecezji.

Kolędnicy misyjni 2008 pospieszyli parafii z pomocą, której owocem jest centrum katechetyczne z ośmioma salami. Zrealizowany został również projekt edukacyjny w zakresie religii i nauczania początkowego.

Wartą do zauważenia działalnością ewangelizacyjną jest realizowanie programów religijnych w radiu (na żywo) i w telewizji (program nagrywany). Audycje mają miejsce raz w tygodniu, a patronuje im i prowadzi je ks. Tomasz.

\subsection{Quevedo}

Quevedo to duże miasto liczące około 200 tys. mieszkańców. Jego dzielnicę San Camilo obejmuje parafia św. Krzysztofa zamieszkiwana przez około 60 tys. mieszkańców. W niedzielę uczestniczy we mszy św. około tysiąc osób. Około 30 proc. mieszkańców parafii obejmującej dzielnicę San Camilo stanowią mieszkańcy slumsów. Na przestrzeni lat obecności naszych księży parafia otrzymała jako dar diecezji tarnowskiej dwa samochody.

Od stycznia 2011 proboszczem parafii jest ks. Mariusz Mikołajczyk, który obowiązki duszpasterskie dzieli z ks. Grzegorzem Dziedzicem.

\subsection{Mocache}

Parafia Matki Bożej Szkaplerznej w Mocache została powierzona księżom tarnowskim w 2004 roku. Proboszczem jest tutaj ks. Witold Machalski. Cała parafia z wioskami (ok. 50 odwiedzanych, a 25 z własnymi kaplicami) liczy około 40 tys. wiernych. Możliwość wyjazdu do wiosek stwarza między innymi samochód zakupiony przez diecezję tarnowską.

\section{Ewangelizacja w Kazachstanie}

Obecność księży diecezji tarnowskiej w Kazachstanie rozpoczęła się wraz z nominacją przez Jana Pawła II w sierpniu 1999 roku ks. Janusz Kalety administratorem apostolskim w Atyrau, którego w dniu 15 września 2006 roku papież Benedykt XVI podniósł do godności biskupiej. W ten sposób bp Wiktor Skworc otworzył kolejny kraj misyjny do pracy dla księży tarnowskich. Ks. bp Janusz od 1999 roku organizuje nowe struktury Kościoła. Na początku tego stulecia 
wybudował kompleks składający się z kościoła pw. Przemienienia Pańskiego, ośrodka duszpasterskiego, w którym mieści się również siedziba administratury. Poza Atyrau otworzył 5 innych parafii na terenie podlegającym jego jurysdykcji. Na potrzeby duszpasterskie Atyrau jako administratury i parafii diecezja tarnowska zakupiła bus i samochód. W dniu 5 lutego Benedykt XVI mianował administratora apostolskiego w Atyrau również biskupem Karagandy. To spowodowało, że nowa diecezja w Kazachstanie cieszy się również obecnością księży z Tarnowa.

$\mathrm{Na}$ dziewięciu tarnowskich księży związanych z ewangelizacją w Kazachstanie, czterech opuściło już ten kraj.

Trzeba też dodać, że na praktyki misyjne do tego kraju już od 2004 roku udaje się w każde wakacje (z wyjątkiem roku 2010) 2-3 kleryków.

\subsection{Atyrau}

Atyrau - stolica administratury jest miastem zamieszkałym przez około 160 tys. ludzi. Zdecydowana większość to muzułmanie. Na tę liczbę przypada 250 katolików, a tych, którzy uczestniczą w niedzielnej mszy św. jest około 100 osób. Od kilkunastu dniu wikariuszem w Atyrau jest ks. Łukasz Niemiec.

Na potrzeby duszpasterskie Atyrau jako administratury i parafii diecezja tarnowska zakupiła samochód.

\subsection{Chromtau}

Parafia pw. Świętej Rodziny w Chromtau (miasto liczące około 25 tys. mieszkańców, gdzie obecna jest również działalność cerkwi prawosławnej), to malutka wspólnota składająca się z ośmiu dorosłych i czworga dzieci. Gromadzą się oni na modlitwę i nabożeństwa w małej kaplicy, zaadoptowanej z połowy domu mieszkalnego.

W maju 2011 roku stanowisko proboszcza objął tu ks. Piotr Kluza, pracujący w Kazachstanie od lipca 2008 roku. Radością i nadzieją ks. Piotra są nieliczni katechumeni. Do chrztu św. przygotowują się dwie osoby dorosłe (matka z córką). Kandydatem jest również dwulatek, a jedna osoba ma przystąpić wkrótce do Komunii św.

Parafia również dysponuje samochodem zakupionym przez diecezje tarnowską.

\subsection{Karaganda}

W latach 30. XX wieku przybywali do Karagandy Polacy deportowani z Polskich Kresów Wschodnich. Katolicy w Karagandzie odznaczali się zawsze wewnętrzną siłą, dlatego została ona nazwana „duchową stolicą” kraju. Zesłani wierni gromadzili się na wspólnej modlitwie we własnych domach, po kryjomu.

W dniu 13 kwietnia 1991 roku Karaganda jako duchowe centrum katolików i miasto męczenników stała się stolicą nowej administratury i siedzibą biskupa. 
W sierpniu 1991 roku została powołana do istnienia parafia pw. św. Józefa w Karagandzie. Proboszczem tej parafii w czerwcu 2011 został ks. Janusz Potok, który do pomocy od połowy września tego roku ma ks. Cezarego Pacieja. W parafii potencjalnych katolików jest około 2 tys., choć dominicantes to tylko 300 osób. Parafia ma ponadto trzy wspólnoty do obsługi poza Karagandą stanowiące razem około 150 osób.

\section{OSADZONA W WIERZE WIELOLETNIA WSPÓŁPRACA MISYJNA}

Deklaracja synodalna, że „Kościół Tarnowski pragnie być wiernym obrazem Kościoła powszechnego, który ze swej natury jest misyjny, przez [...], wysyłanie misjonarzy i współpracę z nimi”, stała się zasadą realizowaną w praktycznym życiu Kościoła, który jest w Tarnowie. Synod więc, by obraz tarnowskiego Kościoła pozostał wiernym odbiciem ducha Kościoła powszechnego, stawia wymóg współpracy z misjonarzami.

\section{Współpraca duchowa i materialna w ramach Diecezjalnego Dzieła Misyjnego}

Powołane przez Synod tarnowski Diecezjalne Dzieło Misyjne, jest przedłużeniem ręki biskupa, który jako posyłający swoich misjonarzy pasterz, troszczy się o duchową i materialną pomoc dla tych jego prezbiterów, którzy stali się darem wiary dla innych Kościołów.

Zaplecze duchowe stanowią modlitwy w czasie comiesięcznych nabożeństw misyjnych w parafiach, których celebracja, z polecenia trzech ostatnich biskupów tarnowskich, jest obowiązkowa. Troska o pomoc duchową dla diecezjalnych misjonarzy wyraża się również w modlitwie grup Diecezjalnego Dzieła Misyjnego istniejących w różach żywego różańca ${ }^{19}$.

Ofiary zaś, które stanowią fundusz Diecezjalnego Dzieła Misyjnego (DDM) pochodzą przede wszystkim: $\mathrm{z}$ nabożeństw misyjnych ${ }^{20}$, z tacy uroczystości Objawienia Pańskiego ${ }^{21}$, która patronuje temu Dziełu, z ofiar składanych przez księży ${ }^{22}$, $\mathrm{z}$ ofiar wspomnianych wyżej grup $\mathrm{DDM}^{23} \mathrm{i}$ z akcji kolędników misyjnych ${ }^{24}$.

19 Na początku roku 2011 było w diecezji 136 parafii, w których róże różańcowe podejmowały tę formę pomocy. W roku 2010 ofiary składane przez róże różańcowe (na PDRW i DDM) wyniosły ponad 230 tys. zt.

20 Za rok 2010 ofiary te wynosiły ponad 582 tys. zł. Zob. Sprawozdanie finansowe: Diecezja Tarnowska 2010. Ofiarność pieniężna i prasa w ramach Papieskich Dziet Misyjnych(PDM) oraz Diecezjalnego Dzieła Misyjnego (DDM), pomoc misjonarzom oraz prasa PDM w parafiach.

${ }_{21}$ Za rok 2010 ofiary te wynosiły ponad 450 tys. zł.

22 Za rok 2010 ofiary te stanowiły wartość ponad 100 tys. zł.

23 Za rok 2010 ofiary te wynosiły ponad 115 tys. zł.

${ }^{24}$ Zebrane w okresie Bożego Narodzenia 2010 ofiary te przekroczyły 1210 tys. zł. 
Pomoc diecezji, zwłaszcza dla misjonarzy w Kongu, mimo nie istnienia jeszcze struktur pomocy, była prowadzona od początku lat siedemdziesiątych. Regularne kształty pomoc ta przybrała w latach dziewięćdziesiątych. Wyraża się ona w subsydiach osobistych dla misjonarzy, zapewnieniu pokrycia kosztów nagłej interwencji medycznej i ewakuacji, zakupie samochodów do pracy misyjnej ${ }^{25}$ czy w subsydiach urlopowych. Formą pomocy dla ludzi pokrzywdzonych przez los, z którymi mają kontakt misjonarze, jest akcja „Mungo Maboko”26.

Szczególną formą pomocy dysponuje fundusz, na który składają się ofiary zebrane przez kolędników misyjnych. Misjonarze realizują projekty składane wcześniej do centrali $\mathrm{DDM}^{27}$. Są to dzieła ewangelizacyjno-socjalne związane przede wszystkim z sytuacją dzieci w krajach misyjnych ${ }^{28}$.

\section{Wizyty pasterskie biskupów tarnowskich}

Współpraca między Kościołem tarnowskim, a posłanymi przezeń fideidonistami wyraża się również przez odwiedziny biskupów tarnowskich w krajach misyjnych.

Biskup Jerzy Ablewicz odwiedził swoich księży w Kongu-Brazzaville na przełomie 1978 i 1979 roku. Była to jednocześnie forma rewizyty biskupowi George Singha, ordynariuszowi diecezji Owando, gdzie do dzisiejszego dnia pracują księża tarnowscy.

W roku 1994 na przełomie stycznia i lutego podróż do Afryki podjął bp Józef Życiński. Odwiedził wtedy misjonarzy diecezjalnych w Kongu-Brazzaville i Republice Środkowoafrykańskiej. Dwa lata później na przełomie lutego i marca złożył również wizytę księżom głoszącym Ewangelię w czterech krajach Ameryki Południowej.

Na przełomie roku 2000-2001 księży w Peru odwiedził bp Wiktor Skworc. W sierpniu 2002 roku przebywał u naszych misjonarzy w Kazachstanie. Zaś na przełomie listopada i grudnia 2004 roku udał się do księży tarnowskich pracujących w Brazylii i Boliwii. Trzecią podróż do Ameryki Łacińskiej w celu odwiedzin swoich księży w Ekwadorze, bp Wiktor Skworc odbył w listopadzie 2005 roku,

25 Por. Wzmianki o samochodach w treści niniejszego artykułu. Do końca roku 2010 DDM zakupiło 110 samochodów i 2 barki (37 samochody na Wschód Europy: Ukrainę - 33, Białoruś - 4; 26 do Afryki; 44 i 2 barki do Ameryki Południowej; 3 do Kazachstanu), a nadto 3 motocykle: 2 do Republiki Środkowoafrykańskiej i 1 do Brazylii. Na początku, w niektórych przypadkach, były to subsydia pokrywające około 80 proc. wartości samochodu.

26 Polega ona na udzieleniu jednorazowej pomocy osobom niepełnosprawnym ruchowo, aby zdołali zorganizować dla siebie formę utrzymania, np. przez handel.

27 Projekty diecezjalne realizowane są od 1999 roku. Do Bożego Narodzenia 2010 roku włącznie przyjęto do realizacji prawie 50 projektów diecezjalnych, na łączną sumę ponad $8 \mathrm{mln}$ 420 tys. zł.

${ }_{28}$ Por. Wzmianki o tych projektach w treści niniejszego artykułu. 
a czwartą w dniach od 6 do 10 grudnia do Boliwii. Okazją do tej wizyty było 300-lecie stolicy wikariatu Conceptión i ewangelizacji na tamtym obszarze.

W dniach od 29 września do 8 października 2008 roku bp Wiktor Skworc przebywał w Republice Konga, gdzie odwiedzał swoich misjonarzy oraz modlił się na grobie ks. Jana Czuby w 10-tą rocznicę męczeńskiej śmierci misjonarza. Kraj ten na przełomie września i października 2010 roku odwiedził również biskup pomocniczy Wiesław Lechowicz. Na początku roku 2009 pasterz diecezji tarnowskiej odbył drugą podróż do Afryki i od 15 do 21 stycznia odwiedzał swoich misjonarzy w Republice Środkowoafrykańskiej, a od 21 do 26 przebywał w Czadzie.

Warto nadmienić o nowatorskim pomyśle bpa Wiktora Skworca, który na czas od 19 do 26 września 2011 roku zaprosił do diecezji tarnowskiej czternastu biskupów tych Kościołów Afryki, Ameryki Południowej i Azji, gdzie posługują tarnowscy misjonarze ${ }^{29}$.

\section{ZAMIAST ZAKOŃCZENIA}

W ciągu 38 lat regularnego posyłania misjonarzy, uwzględniając pierwsze zwiastuny otwartości na Kościół powszechny na początku lat sześćdziesiątych ubiegłego stulecia, biskupi tarnowscy posłali 118 księży: do Afryki 52, do Ameryki Południowej 64 i do Azji 9. W śród nich siedmiu księży zmieniło kraj misyjny, przynajmniej na pewien czas: dwóch w Afryce, czterech w Ameryce Południowej i jeden z Afryki na kraj w Ameryce ${ }^{30}$. Posłali również 8 misjonarzy świeckich do Afryki i dwanaście wolontariuszek na kontynent afrykański i amerykański.

Abp Jerzy Ablewicz posłał 36 misjonarzy, abp Józef Życiński 26 misjonarzy i bp Wiktor Skworc 56 misjonarzy kapłanów-fidei donum.

Obecnie w ramach Diecezjalnego Dzieła Misyjnego (DDM) diecezji tarnowskiej pracuje 46 księży misjonarzy: w Afryce 14 (Czad - 1, Rep. Konga - 4, Rep. Środkowoafrykańska - 9), w Ameryce Łacińskiej 27 (Argentyna - 2, Peru - 9, Boliwia - 4, Brazylia - 6, Ekwador - 6), w Azji 5 (Kazachstan). Stanowią oni 15 proc. fideidonistów polskich.

Misjonarze świeccy: w Kamerunie (1) i Republice Środkowoafrykańskiej (3) i oraz 2 wolontariuszy (Rep. Środkowoafrykańska).

W roku szkolnym 2011/2012 w CeFoM w Warszawie do pracy w Afryce przygotowuje się dwóch kapłanów oraz dwóch we Francji1 ${ }^{31}$.

29 Por. K. Czermak, „Głoście Ewangelię” 4 (2011), s. 5-11.

30 Niektórzy księża zostali posłani do dwóch krajów w Afryce czy Ameryce Południowej. Ks. Jan Piotrowski jest jedynym misjonarzem tarnowskim, który pracował na dwóch kontynentach.

31 Stan z 15 września 2011 roku. 


\section{RECENT MISSIONARY COMMITMENT \\ OF TARNOW DIOCESE WITHIN THE CONTEXT OF 225 ANNIVERSARY OF ITS EXISTENCE}

\section{Summary}

In the above presentation the Diocese of Tarnow has shown its commitment to the missionary work at the time of celebrating its 225 jubilee. It covers the last 38 years because during that time the bishops of Tarnow have regularly sent forth the missionaries to different countries. This commitment by reading the spirit and intentions of Vatican II, had been started by archbishop George Ablewicz and then continued by successive bishops of Tarnow: namely by bishop Joseph Życiński and the bishop Victor Skworc. So far they have sent forth 118 priests to three different continents. This act harmonizes with the fourth Synod of the Diocese of Tarnow which took place in 1986. Its main motto was "Ad imaginem Ecclesiae universalis". This life of the particular Church which in Tarnow is following the example of the universal Church is mainly expressed by sending forth the missionaries and then in cooperation with them. Their work is a huge contribution to the evangelization of the few countries in Africa, South America and more recently Kazakhstan in Asia. Upon this commitment has been placed a seal of the martyrdom of one of the sons of the Diocese of Tarnow - namely the priest John Czuba, the fideidonist, who was killed in the Republic of Congo in 1998.

The missionary cooperation of the Diocese is both spiritual and material. It is done thanks to the Diocesan Missionary Work. It is expressed in constant prayer for the missionaries undertaken especially by the rosary groups, but also by maintaining the missionaries, purchase of the means of transport for them or making investments, among which are: hospitals, schools, kindergartens or home for the street children. They are used by children and adults and the priest of Church of Tarnow tend them.

At present in the Diocesan Missionary Work there are 46 missionaries from Tarnow region. They work in different parts of the world: 14 of them stay in Africa, 27 work in South America and 5 in Kazakhstan. This represents approximately 15 per cent of all fideidonists in Poland. To this number we may add the secular missionaries who work in the following countries: Cameroon - there is one missionary, the Central African Republic - there are two missionaries and two other volunteers in this very country.

\section{Keywords}

sending forth the missionaries - the duty of the Church in proclaiming the Gospel; missionary cooperation - participation in missionary work of the universal Church or particular Church in proclaiming the Gospel. 
